\title{
Optimization of HS-SPME analytical conditions using factorial design for trihalomethanes determination in swimming pool water samples
}

\author{
Raquel Maia, Manuela Correia, Isabel M. Brás Pereira, Vitorino M. Beleza
}

\author{
$\mathrm{a} b \mathrm{~s} t \mathrm{r}$ a c t
}

Trihalomethanes (THMs) are widely referred and studied as disinfection by-products (DBPs). The THMs that are most commonly detected are chloroform (TCM), bromodichloromethane (BDCM), chlorodibromomethane (CDBM), and bromoform (TBM). Several studies regarding the determination of THMs in swimming pool water and air samples have been published. This paper reviews the most recent work in this field, with a special focus on water and air sampling, sample preparation and analytical determination methods.

An experimental study has been developed in order to optimize the headspace solid-phase microextraction (HS-SPME) conditions of TCM, BDCM, CDBM and TBM from water samples using a $2^{3}$ factorial design. An extraction temperature of $45^{\circ} \mathrm{C}$, for $25 \mathrm{~min}$, and a desorption time of 5 min were found to be the best conditions. Analysiswas performed by gas chromatography with an electron capture detector (GC-ECD).

The method was successfully applied to a set of 27 swimming pool water samples collected in the Oporto area(Portugal). TCM was the only THM detected with levels between 4.5 and $406.5 \mu \mathrm{g} \mathrm{L}^{-1}$. Four of the samples exceeded the guideline value for total THMs in swimming pool water $\left(100 \mu \mathrm{g} \mathrm{L}{ }^{-1}\right)$ indicated by the PortugueseHealth Authority.

\section{Introduction}

Swimming pools require disinfection for inactivation of pathogen microorganisms. Halogenated compounds are often selected for this purpose. However, the reaction between chlorine or bromine, and organic precursors present in swimming pool water, derived from the water source and the pool users (urine, saliva, sweat, hair, cosmetics and others) may originate various disinfection by-products (DBPs) [1].

Trihalomethanes (THMs) are one of the most common groups of DBPs. Chloroform (TCM), bromodichloromethane (BDCM), chlorodibromomethane (CDBM) and bromoform (TBM) are the THMs more often detected. TCM often occurs at the greatest concentration in swimming pool water when chlorine is the preferred disinfection agent [1] and if the makeup water has a reduced concentration of bromide (which is not the case when using seawater, for example). Since THMs are volatile halogenated hydrocarbons, factors such as temperature and concentration levels found in indoor swimming pool water enhance their transfer from water to air. The formation of these compounds has drawn public attention due to their possible link to health effects in users and staff of such installations [1]. The International Agency for Research on Cancer (IARC) has classified TCM as a type $2 \mathrm{~B}$ carcinogen (possible carcinogen) [2]. There is an association between an increased risk for some cancers and the consumption of chlorinated water. However, the reported epidemiological studies do not allow a straight conclusion of the individual effect of chloroform, by its own, on that correlation as there are other factors as well as other compounds (other chlorination by-products) that may confound that association [2]. So, the IARC evaluation states sufficient evidence in experimental animals and inadequate evidence in humans for the carcinogenicity of chloroform, which leads to the overall conclusion that chloroform is possibly carcinogenic to humans (group 2B) [2]. For bromodichloromethane there is also sufficient evidence for the carcinogenicity in experimental animals but any epidemiological study in humans is reported by IARC [3,4]. This leads to a similar overall evaluation of BDCM as possibly carcinogenic to humans (group 2B) [3,4].

The distribution of these compounds between liquid and gaseous phases is pertinent, either in real operating conditions or in analytical procedures for their quantification. TCM is the most volatile component followed by BDCM, CDBM and TBM [5-7]. The corresponding Henry's constants (in atm $\mathrm{m}^{3} \cdot \mathrm{mol}^{-1}$, at $20^{\circ} \mathrm{C}$ ) are $3 \times 10^{-3}(\mathrm{TCM})$ [5], $2.41 \times 10^{-3}(\mathrm{BDCM})[6], 9.9 \times 10^{-4}(\mathrm{CDBM})[7]$ and $5.6 \times 10^{-4}$ (TBM) [7]. 

THMs are the most frequently measured and best studied DBP. THMs' levels will vary as a consequence of the concentration of precursor compounds, disinfectant dose, concentration of THMs in the makeup water, residual disinfectant level, temperature and $\mathrm{pH}$ [1]. Research has been carried out in several countries, to determine the concentration of THMs and assess the exposure to these compounds in indoor swimming pools [8-21]. Table 1 summarizes the mean and the ranges of THM concentration in water and air samples reported in these studies.

Several authors have documented significant quantities of THMs and particularly TCM in swimming pools. As regards the values presented in Table 1, total THMs and TCM concentrations varied between 4.8 and $1224 \mu \mathrm{g} \mathrm{L}^{-1}$, and between 0.08 and $980 \mu \mathrm{g} \mathrm{L} \mathrm{L}^{-1}$, respectively, in swimming pool waters. However, the average TCM concentration did not exceed $200 \mu \mathrm{g} \mathrm{L}^{-1}$. Regarding the concentration of THMs and TCM in air, levels ranging from 1.45 to $1225 \mu \mathrm{g} \mathrm{m}^{-3}$, and 1.7 to $853 \mu \mathrm{g} \mathrm{m}^{-3}$, respectively, were observed (Table 1).

Generally, lower values were reported for BDCM, CDBM and TBM, except in recent studies [20,21], where the use of different disinfection agents, chlorine and bromine, were compared. For the first case, TCM predominates, and for the other, TBM becomes the dominant THM.

Earlier studies, such as Lahl et al. [11] and Aggazzotti et al. [14] reported the highest concentrations of TCM in water and indoor air, respectively. On the other hand, recent studies show that, generally, TCM values have been decreasing over time which may suggest a change in behaviour on the handling of disinfectants.
There is no specific European legislation for THMs in swimming pool water and air [18], but in many countries guideline values are used as reference. For THMs in water, the guideline value often adopted $\left(100 \mu \mathrm{g} \mathrm{L}^{-1}\right)$ is the one established for drinking water quality (Directive 98/83/EC [22]). The Portuguese Health Authority adopted this value $\left(100 \mu \mathrm{g} \mathrm{L}^{-1}\right)$ as the maximum concentration for total THMs in swimming pool water [23]. Other European countries, individually, have already established a maximum value for THMs in swimming pool water, as is the case of Germany with a limit of $20 \mu \mathrm{g} \mathrm{L}^{-1}$ and Denmark with a maximum level of $50 \mu \mathrm{g} \mathrm{L}^{-1}[8]$. Other countries and organizations have suggested different guideline values for THMs in drinking water. The United States Environmental Protection Agency (USEPA) sets a value of $80 \mu \mathrm{g} \mathrm{L}^{-1}$ [24] for total THMs, the World Health Organization (WHO) establishes different guideline values for each THM, namely, 300 $\mu \mathrm{g} \mathrm{L}^{-1}$ for TCM, $60 \mu \mathrm{g} \mathrm{L}{ }^{-1}$ for BDCM, and $100 \mu \mathrm{g} \mathrm{L}^{-1}$ for both CDBM and TBM [25]. Canada has set the maximum acceptable concentrations of $16 \mu \mathrm{g} \mathrm{L}^{-1}$ for BDCM and $100 \mu \mathrm{g} \mathrm{L}^{-1}$ for total THMs [26].

As regards THMs in air, parametric values for occupational exposure to chemical hazards [27-30] may be used as reference (Table 2). These parametric values are higher than the THMs concentrations reported in swimming pool air samples (Table 1).

Sampling is one of the most important steps in sample analysis and is crucial for the quality of the results. As regards swimming pool water samples for THMs analysis, it is necessary to quench any residual

Table 1

Mean and ranges of THMs concentration in water $\left(\mu \mathrm{g} \mathrm{L}^{-1}\right)$ and $\operatorname{air}\left(\mu \mathrm{g} \mathrm{m}^{-3}\right)$ in indoor swimming pools (literature review).

\begin{tabular}{|c|c|c|c|c|c|c|c|c|c|c|c|c|c|c|c|c|}
\hline \multirow[t]{2}{*}{ Country } & \multirow[t]{2}{*}{ Sample } & \multirow[t]{2}{*}{$\mathrm{N}$} & \multirow[t]{2}{*}{$\mathrm{n}$} & \multicolumn{2}{|l|}{ THMs } & \multicolumn{2}{|l|}{ TCM } & \multicolumn{2}{|l|}{ BDCM } & \multicolumn{2}{|l|}{ CDBM } & \multicolumn{2}{|l|}{ TBM } & \multirow{2}{*}{$\begin{array}{l}\text { Disinfection } \\
\text { agent }\end{array}$} & \multirow{2}{*}{$\begin{array}{l}\text { Year } \\
\text { reported }\end{array}$} & \multirow[t]{2}{*}{ Ref. } \\
\hline & & & & Mean & Range & Mean & Range & Mean & Range & Mean & Range & Mean & Range & & & \\
\hline \multirow{2}{*}{$\begin{array}{l}\text { China } \\
\text { (Taiwan) }\end{array}$} & Water & 1 & 8 & & & 9.81 & $7.96-12.44$ & & & & & & & \multirow[t]{2}{*}{$\mathrm{Cl}$} & \multirow[t]{2}{*}{2011} & \multirow[t]{2}{*}{ [9] } \\
\hline & Air & 1 & 8 & & & $13.97^{\mathrm{a}}$ & $11.34-17.04^{\mathrm{a}}$ & & & & & & & & & \\
\hline \multirow[t]{2}{*}{ France } & Water & 15 & 185 & & $4.8-80.7$ & & $3.5-72.6$ & & $0.6-15.3$ & & $0.35-3.8$ & & $0.35-2.2$ & $\mathrm{Cl}$ & 2011 & [10] \\
\hline & Air & 15 & 185 & & $1.45-793$ & & & & & & & & & & & \\
\hline \multirow[t]{4}{*}{ Germany } & Water & 8 & - & 233.3 & $59-1224$ & 198 & $43-980$ & 22.6 & $0.1-150$ & 10.9 & $0.1-140$ & 1.8 & b0.1-88 & $\mathrm{Cl}$ & 1981 & [11] \\
\hline & Air & 8 & - & & & 116.6 & $10-384$ & 9.5 & $0.1-39$ & & & & & & & \\
\hline & Water & 1 & 3 & & & 17.5 & $7-24.8$ & & & & & & & $\mathrm{Cl}$ & 2004 & [12] \\
\hline & $\mathrm{Air}^{\mathrm{b}}$ & 1 & 3 & & & 188.3 & $120-235$ & & & & & & & & & \\
\hline \multirow[t]{10}{*}{ Italy } & Water & 2 & 8 & & & 3 & $19-94$ & & & & & & & $\mathrm{Cl}$ & 1993 & [13] \\
\hline & $\operatorname{Air}^{c}$ & 2 & 8 & & & 139 & $49-280$ & & & & & & & & & \\
\hline & Water & 12 & 88 & & & 65 & $9-179$ & & & & & & & $\mathrm{Cl}$ & 1995 & [14] \\
\hline & $\mathrm{Air}^{\mathrm{c}}$ & 12 & 88 & & & 222 & $16-853$ & & & & & & & & & \\
\hline & Water & 1 & 4 & & & 34 & $25-43$ & 2.3 & $1.8-2.8$ & 0.8 & $0.5-10$ & 0.1 & 0.1 & $\mathrm{Cl}$ & 1998 & [15] \\
\hline & $\mathrm{Air}^{\mathrm{c}}$ & 1 & 4 & & & 169 & $135-195$ & 20 & $16-24$ & 11.4 & $9-14$ & - & 0.2 & & & \\
\hline & Water & 5 & 5 & 39.8 & $17.8-70.8$ & 33.2 & $6.1-68.4$ & 4.2 & $2-5.3$ & 1.9 & $0.4-5.4$ & 0.4 & b0.1-1.3 & $\mathrm{Cl}$ & 2001 & [16] \\
\hline & Air & 5 & 5 & 58.0 & $33-86.7$ & 46.1 & $19-67.7$ & 8.7 & $2.9-14.7$ & 3.1 & $0.3-6$ & 0.8 & & & & \\
\hline & Water & 4 & 20 & & & 36.8 & $10.2-127$ & 4.8 & $0.3-19.2$ & 3.6 & $0.5-20.4$ & 0.8 & $0.13-5.9$ & $\mathrm{Cl}$ & 2010 & [17] \\
\hline & $\mathrm{Air}^{\mathrm{c}}$ & 4 & 26 & & & 85 & $21-182$ & & & & & & & & & \\
\hline \multirow[t]{5}{*}{ Portugal } & Water & 4 & 20 & & $22-577$ & & $18-520$ & & & & & & & $\mathrm{Cl}$ & 2011 & [8] \\
\hline & $\operatorname{Air}^{\mathrm{d}}$ & 4 & 20 & & $98-1225$ & & & & & & & & & & & \\
\hline & $\mathrm{Air}^{\mathrm{c}}$ & 4 & 16 & & 51-906 & & & & & & & & & & & \\
\hline & Water & 30 & 180 & & $10.1-155$ & & $6.3-151$ & & $1.0-21.5$ & & $1.0-10$ & & $1.0-5.9$ & $\mathrm{Cl}$ & 2012 & [18] \\
\hline & $\mathrm{Air}^{\mathrm{e}}$ & 30 & 180 & & & & $45-373$ & & & & & & & & & \\
\hline \multirow[t]{10}{*}{ Spain } & Water & 20 & 40 & 15.8 & & 13.7 & & 1.4 & & 0.5 & & 0.3 & & $\mathrm{Cl}$ & 2009 & [19] \\
\hline & $\operatorname{Air}^{\mathrm{b}}$ & 20 & 40 & & & 22.0 & & & & & & & & & & \\
\hline & Water & 1 & 68 & 49.6 & $35.2-75.2$ & 15.4 & $8.4-20.8$ & 14.2 & $9.3-26.8$ & 12.8 & $6.5-22.6$ & 7.2 & $3.0-16.5$ & $\mathrm{Cl}$ & 2010 & [20] \\
\hline & $\operatorname{Air}^{\mathrm{f}}$ & 1 & 68 & 72.1 & $44.0-124.9$ & 32.1 & $11.9-61.6$ & 14.9 & $7.5-23.4$ & 14.0 & $6.1-26.2$ & 11 & $4.4-22.6$ & & & \\
\hline & Water & 1 & 12 & 60.2 & $54.4-67.2$ & 0.2 & $0.1-0.3$ & 0.4 & $0.2-0.7$ & 2.4 & $2.1-2.7$ & 57.2 & $52.0-64.3$ & $\mathrm{Br}$ & & \\
\hline & $\operatorname{Air}^{f}$ & 1 & 12 & 89.5 & $63.1-124.7$ & 4.4 & $1.7-9.4$ & 2.9 & $1.7-4.8$ & 7.3 & $6.1-9.7$ & 74.9 & $53.3-101.4$ & & & \\
\hline & Water & 1 & 70 & & & 15 & $8.5-20$ & 14 & $9.4-25$ & 13 & $6.7-23$ & 7.2 & $3.1-16$ & $\mathrm{Cl}$ & 2012 & [21] \\
\hline & $\operatorname{Air}^{f}$ & 1 & 82 & & & 32 & $18-61$ & 15 & $8.2-23$ & 14 & $6.4-22$ & 11 & $5.9-22$ & & & \\
\hline & Water & 1 & 9 & & & 0.21 & $0.08-0.29$ & 0.41 & $0.23-0.6$ & 2.4 & $2.1-2.6$ & 60 & $52-61$ & $\mathrm{Br}$ & & \\
\hline & $\operatorname{Air}^{\mathrm{f}}$ & 1 & 10 & & & 4.5 & $1.8-6.9$ & 3.0 & $1.9-4.2$ & 7.3 & $6.4-8.7$ & 75 & $55-92$ & & & \\
\hline
\end{tabular}

$\mathrm{N}$ - number of swimming pools; $\mathrm{n}$ - number of independent samples, when available.

${ }^{\text {a }}$ Estimated value.

b $20 \mathrm{~cm}$ above the water surface.

c $150 \mathrm{~cm}$ above the water surface.

${ }^{\mathrm{d}} 5 \mathrm{~cm}$ above the water surface.

$30 \mathrm{~cm}$ above the water surface.

f $60 \mathrm{~cm}$ above the water surface. 
Table 2

Parametric and guideline values for occupational exposure to THMs.

\begin{tabular}{|c|c|c|c|c|c|}
\hline \multirow[b]{2}{*}{ Legislation } & \multicolumn{5}{|c|}{ Limitvalues $\left(\mathrm{mg} \mathrm{m}^{-3}\right)$} \\
\hline & $\mathrm{TCM}$ & BDCM & CDBM & TBM & THMs \\
\hline $\begin{array}{l}\text { Directive 2000/39/EC [27] } \\
\text { (indicative limit values) }\end{array}$ & $10^{\mathrm{a}}$ & & & & \\
\hline OSHA [28] (guideline value) & $240^{\mathrm{b}}$ & & & $5^{b}$ & $240^{\mathrm{b}}$ \\
\hline NIOSH [29] (guideline value) & $9.78^{\mathrm{c}}$ & & & $5^{\mathrm{a}}$ & \\
\hline ACGIH [30] (guideline value) & $49^{\mathrm{a}}$ & & & $5.2^{\mathrm{a}}$ & \\
\hline
\end{tabular}

ACGIH - American Conference of Governmental Industrial Hygienists; NIOSH - National Institute for Occupational Safety and Health; OSHA - Occupational Safety and Health Administration.

${ }^{\text {a }}$ Time-weighted average (TWA).

${ }^{\mathrm{b}}$ Permissible exposure limit(PEL)

${ }^{c}$ Short-term exposure limit (STEL).

chlorine reaction after the moment of sample collection. Sodium thiosulphate is commonly added [16], although ascorbic acid may also be used as a dechlorination agent [31,32].

Parameters such as water and air temperatures, $\mathrm{pH}$, free and combined residual chlorine, total organic content (TOC) and the number of swimmers present in the pool should be monitored because of their relation with THMs concentration. With the exception of TOC, all those parameters are measured in the collection site.

Air sample collection may be accomplished using different techniques, often dictated by the analysis method. When using sorbent tubes, a sampling pump is used to collect an adequate volume of air that flows through the tube, allowing the compounds to be retained in the sorbent. For the analysis of many gases and vapours, air samples can be collected conveniently using flexible plastic bags. These bags are commercially available in a variety of sizes and materials. Plastic bags are light, unbreakable and are easily filled from a completely collapsed state with a one-way bulb, syringe or small pump [33].

Water and air sampling conditions may vary significantly, especially the sampling site within the pool (1 corner, 2 opposite corners, 4 corners, etc.) and the distance of collection, either from the edges or from the water surface (Table 3). As an example, different heights have been suggested for air sample collection, ranging from 5 to $150 \mathrm{~cm}$ above water surface.

Many studies have been published on the analysis of THMs in drinking waters including the review paper of Pavón et al. [34]. However, there is considerably less information about the analysis of THMs in swimming pool waters. In all the referred studies, THMs are analysed by gas chromatography. Together with direct sample injection, several sample preparation and extraction methods used in the analysis of swimming pool water and air samples are presented below $[8,11,12,15,16,18,19,21,36-45]$.

Direct aqueous injection (DAI), liquid-liquid extraction (LLE), static headspace (HS), purge and trap (P\&T) and headspace solid phase microextraction (HS-SPME) are the main techniques used for water sample preparation prior to gas chromatographic (GC) analysis. For air samples, direct injection (DI), P\&T, HS-SPME and solid sorbents are commonly used.

As chromatographic detectors, ECD (electron capture detector) and MS (mass spectrometry) detector are the most often used.

Direct aqueous injection of water samples is a simple and fast procedure for determination of THMs [35,36]. However this technique has problems with column stability and critical temperatures for column and injector [35]. To reduce this problem, pre-columns are often used. Table 4 summarizes the main applications based on this sample preparation technique.

Liquid-liquid extraction is a simple but laborious method used to separate compounds based on their relative solubility in two immiscible liquids. LLE is time-consuming, expensive and requires the evaporation of large amounts of solvent and the disposal of toxic chemicals [35]. EPA Methods 501.2 and 551.1, Standard Method 6232B and ISO 10301 for the determination of THMs in water samples are based on the use of LLE. Table 4 presents some of the features of the LLE methods reported by several authors.

A new microextraction method named dispersive liquid-liquid microextraction (DLLME) for determination of TCM in pool water is described by Shegefti et al. [35]. A sample volume of $1 \mathrm{~mL}$ was extracted with $0.39 \mathrm{~mL}$ of methanol (disperser solvent) and $20 \mu \mathrm{L}$ of trichloroethylene (extraction solvent). The extraction was performed in $3 \mathrm{~min}$ and the GC run time lasted for $10 \mathrm{~min}$, with acceptable reproducibility (RSD in the range 2.9-6.3\%).

Another widely used technique for the extraction of volatile compounds is static headspace (HS). It is a simple method that allows a large number of samples to be screened in a relatively short period of time [35]. Generally, a headspace autosampler is coupled to a GC instrument, but it can be directly coupled to a MS detector for the determination of total THMs in drinking water [42]. Static HS is one of the preferred extraction methods for the determination of THMs in swimming pool water samples (Table 4). This method is also referred in standard methods, such as ISO 10301.

The main advantage of this configuration is that sample treatment is reduced to a minimum [34]. In HS method, which relies in a phase's equilibrium the collection of the volatile compounds of the sample is always partial. This leads to concern about sensitivity [34]. If a large sample volume is used in order to improve sensitivity, the increase in the initial peak bandwidth will be a disadvantage [34]. HS is relatively less sensible when compared to LLE [34].

The purge and trap (P\&T) system consists of a purging device, and a column of adsorbent material (trap) that holds the analytes. The trap is then heated and the sample compounds are introduced in the GC column. Standard Method 6232C and US EPA Methods 501.1, 524.2, and $5030 \mathrm{~B}$ and $\mathrm{C}$ make use of this extraction technique. The conditions used in several studies for the determination of THMs by P\&T are summarized in Table 4.

Table3

Water and air sampling conditions (literature review).

\begin{tabular}{|c|c|c|c|c|c|c|c|c|}
\hline & Ref. & {$[8]$} & [15] & [16] & [18] & [19] & {$[20]$} & {$[21]$} \\
\hline \multirow{5}{*}{$\begin{array}{l}\text { Water } \\
\text { sampling }\end{array}$} & Sample volume $(\mathrm{mL})$ & 40 & 40 & 40 & 15 & 50 & 40 & $40^{\mathrm{a}}$ \\
\hline & $\begin{array}{l}\text { Dechlorination agent } \\
\left(\mathrm{Na}_{2} \mathrm{~S}_{2} \mathrm{O}_{3}\right)\end{array}$ & & $5 \mathrm{mg}$ & $5 \mathrm{mg}$ & & $150 \mu \mathrm{L}(10 \%)$ & $5 \mathrm{mg}$ & $3 \mathrm{mg}$ \\
\hline & $\operatorname{Depth}(\mathrm{cm})$ & 20 & 20 & 20 & & 20 & & \\
\hline & Distance from edges & $1 \mathrm{~m}$ & Near theedge & Near theedge & & $1 \mathrm{~m}$ & & \\
\hline & Sampling sites & 4 corners & 3 & & 2 opposite corners & & & 4 corners \\
\hline \multirow[t]{7}{*}{ Air sampling } & Sampling sites & 1 & 2 & & 2 & 2 opposite corners & & \\
\hline & Height & 5 and $150 \mathrm{~cm}$ & $150 \mathrm{~cm}$ & & $30 \mathrm{~cm}$ & $10-20 \mathrm{~cm}$ & $60 \mathrm{~cm}$ & $60 \mathrm{~cm}$ \\
\hline & Distance from edges & $10 \mathrm{~cm}$ & & & & & $1.5 \mathrm{~m}$ & $1.5 \mathrm{~m}$ \\
\hline & Collection method & Direct collection & Direct collection & Tedlar bags & Activated carbontubes & Direct collection & Sorbent tubes & Sorbent tubes \\
\hline & Volume & $40 \mathrm{~mL}$ & $40 \mathrm{~mL}$ & $2 \mathrm{~L}$ & $24 \mathrm{~L}$ & $15 \mathrm{~L}$ & $140 \mathrm{~mL}$ & $140 \mathrm{~mL}$ \\
\hline & Pumpflow rate & $1 \mathrm{~L} \mathrm{~min}^{-1}$ & & $15 \mathrm{~mL} \mathrm{~min}^{-1}$ & $200 \mathrm{~mL} \mathrm{~min}^{-1}$ & $1 \mathrm{~L} \mathrm{~min}^{-1}$ & $7 \mathrm{~mL} \mathrm{~min}^{-1}$ & $7 \mathrm{mLmin}^{-1}$ \\
\hline & Sampling time & $1 \mathrm{~min}$ & & $2 \mathrm{~h}$ & $2 \mathrm{~h}$ & $15 \mathrm{~min}$ & $20 \mathrm{~min}$ & $20 \mathrm{~min}$ \\
\hline
\end{tabular}

a From a $1 \mathrm{~L}$ composite sample $(4 \times 250 \mathrm{~mL})$. 
Determination of THMs in swimming pool water samples (literature review).

\begin{tabular}{|c|c|c|c|c|c|}
\hline Instrumental configuration & Extraction andinjection & $\begin{array}{l}\text { GCruntime } \\
(\min )\end{array}$ & $\begin{array}{l}\text { RSD } \\
(\%)\end{array}$ & $\begin{array}{l}\mathrm{LOD} \\
\left(\mu \mathrm{g} \mathrm{L} \mathrm{L}^{-1}\right)\end{array}$ & Ref. \\
\hline DAI/GC-ECD & $\begin{array}{l}\text { Pre-column: } 2 \mathrm{~m} \times 0.32 \mathrm{~mm} \text { i.d. } \\
\text { Injection: Cold on column, } 2 \mu \mathrm{L}\end{array}$ & n.s. & b3 & 0.01 & [36] \\
\hline DAI/GC-ECD & $\begin{array}{l}\text { Pre-column: RTX } 6256 \mathrm{~m} \times 0.53 \mathrm{~mm} \text { i.d. } \\
\text { Injection: Cold on column, } 4 \mu \mathrm{L}\end{array}$ & 31 & $2.1-3$ & $0.3-0.4$ & [37] \\
\hline LLE/GC-MS & Organic solvent: $n$-pentane & n.s. & \pm 10 & $0.03-0.1$ & [11] \\
\hline LLE/GC-ECD & Organic solvent: $n$-pentane & n.s./n.s. ${ }^{\mathrm{a}}$ & $2.9-6.8$ & n.s. & [19] \\
\hline LLE/GC-ECD & $10 \mathrm{~mL}$ of water sample and $1 \mathrm{~mL}$ of hexane & $0.5 / 31^{\mathrm{a}}$ & $4-7.3$ & $0.06-0.07$ & [37] \\
\hline HS/GC-ECD & Samples were equilibrated at $45^{\circ} \mathrm{C}$ for $60 \mathrm{~min}$ and then injected in the $\mathrm{GC}$ & $60 / 68$ & b10 & n.s. & [12] \\
\hline HS/GC-ECD & n.s. & n.s. & $1.13-3.6$ & 0.1 & [15] \\
\hline HS/GC-ECD & n.s. & n.s. $/ 24.7$ & $1.13-3.6$ & 0.1 & [16] \\
\hline HS/GC-ECD & $\begin{array}{l}\text { Samples were equilibrated at } 70^{\circ} \mathrm{C} \text { for } 27 \mathrm{~min} \text { in a HS analyser. A subportion of } \\
\text { HS gas was transferred through a needle }\left(100^{\circ} \mathrm{C}\right) \text { and transfer line }\left(120^{\circ} \mathrm{C}\right) \text { to the GC }\end{array}$ & $27 / 12^{\mathrm{a}}$ & b5 & 2.5 & [38] \\
\hline HS/GC-ECD & n.s. & n.s. $/ 10^{\mathrm{a}}$ & $1.8-6.7$ & $0.03-0.07$ & [39] \\
\hline HS/GC-ECD & $\begin{array}{l}5 \mathrm{~mL} \text { of water sample were placed into a } 10 \mathrm{~mL} \text { vial. The sample was heated at } 37^{\circ} \mathrm{C}(1 \mathrm{~h}) \\
100 \mu \mathrm{L} \text { of the } \mathrm{HS} \text { sample were injected into the GC using a gas-tight syringe }\end{array}$ & 60/n.s. ${ }^{\mathrm{a}}$ & n.s. & 0.1 & [40] \\
\hline HS/GC-MS & HS autosampler & $10 / 16^{\mathrm{a}}$ & b4.5 & $0.5-0.6$ & {$[41]$} \\
\hline HS-MS & $\begin{array}{l}12 \mathrm{~mL} \text { of water sample } 0.1 \mathrm{M} \text { in ascorbic acid were placed into a } 20 \mathrm{~mL} \text { vial containing } \\
3 \mathrm{~g} \mathrm{KCl} \text {. The sample was heated at } 80^{\circ} \mathrm{C}(10 \mathrm{~min}) \text { with mechanical agitation }\end{array}$ & & $3.7-4.2$ & $1-1.2$ & [42] \\
\hline P\&T/GC-ECD & $16 \mathrm{~cm}$ length, $0.4 \mathrm{~cm}$ i.d. tube packed with $0.04 \mathrm{~g}$ of Tenax TA between two layers of silanized wool & $10 / 5 / 25^{\mathrm{b}}$ & $1.4-4.5$ & $0.004-0.015$ & [21] \\
\hline P\&T/GC-DELCD & n.s. & n.s./n.s. $/ 28^{\mathrm{b}}$ & $1.2-4.0$ & $0.6-0.9$ & [37] \\
\hline P\&T/GC-MS & n.s. & $11 / 4 / 59^{\mathrm{b}}$ & & 0.2 & [43] \\
\hline P\&T/GC-ECD & $30 \mathrm{~cm}$ adsorbent trap (Tenax/silica gel/charcoal) & $11 / 4 / 84^{\mathrm{b}}$ & & $0.02-0.03$ & [44] \\
\hline HS-SPME/GC-ECD & $\begin{array}{l}100 \mu \mathrm{m} \text { PDMS fibre; } 1.6 \mathrm{~mL} \text { sample into a } 4 \mathrm{~mL} \text { vial; } 300 \mathrm{rpm} ; 55^{\circ} \mathrm{C} \\
\text { Calibration range: } 0.5-19.5 \mu \mathrm{g} \mathrm{L}^{-1}\end{array}$ & $10 / 10 / 18^{\mathrm{c}}$ & $5-10$ & $0.1-0.5$ & {$[8]$} \\
\hline HS-SPME/GC-ECD & $\begin{array}{l}100 \mu \mathrm{m} \text { PDMS fiber; } 0.8 \mathrm{~mL} \text { sample } ; 20 \pm 3^{\circ} \mathrm{C} \\
\text { Calibration range: } 2.2-160 \mu \mathrm{g} \mathrm{L} \\
-1\end{array}$ & $10 / 5 / 16.85^{c}$ & & & [18] \\
\hline HS-SPME/GC-MS & $\begin{array}{l}100 \mu \mathrm{m} \text { PDMS fibre; } 2 \mathrm{~mL} \text { sample into a } 4 \mathrm{~mL} \text { vial; } 250 \mathrm{rpm} ; 20 \pm 1^{\circ} \mathrm{C} \\
\text { Calibration range: } 10-160 \mu \mathrm{g} \mathrm{L}\end{array}$ & $20 / 2 / 9.7^{\mathrm{c}}$ & $0.9-19$ & $1-2.8$ & [45] \\
\hline
\end{tabular}

DELCD - Dry electrolytic conductivity detector; LOD - limit of detection; n. s. - not specified; R.S.D. - Relative Standard Deviation.

${ }^{a}$ Extraction time $(\mathrm{min}) / \mathrm{GC}$ run time $(\mathrm{min})$.

${ }^{\text {b }}$ Purge time (min)/desorption time ( $\left.\mathrm{min}\right) / \mathrm{GC}$ run time (min).

Extraction time (min)/desorption time (min)/GC run time (min)

P\&T is more time consuming and requires a special apparatus. However, sample preparation is reduced, a large amount of sample can be injected into the system and excellent precision of this method has been demonstrated for THMs analysis [45].

HS-SPME is a solvent-free sampling technique based on the sorption characteristics of fibre coating materials. This technique has been successfully applied to the extraction of volatile organic compounds (VOCs) in various matrices [45], including the determination of THMs in swimming pool waters (Table 4). SPME is, in its essence, a nonexhaustive extraction technique that is based on a partition equilibrium between the concentrations of the analytes distributed by the several phases involved (e.g., fibre coating, headspace, and liquid phase, as in the case of the analysis of THMs in water samples confined in a closed vial by HS-SPME). This technique is also particularly prone to matrix effects and care must be taken when it is applied to different matrices. However, since 1990, when it was first reported there has been sufficient evidence of the many advantages of SPME. The possibility of automation, the absence of toxic and expensive organic solvents that have to be further disposed, and the simplification in the sample extraction procedures when compared to other techniques [34] have made this the elected extraction technique in many accredited methods, as in the case of THMs analysis in both drinking and

swimming pool water samples.

Despite all the advantages of HS-SPME, some difficulties have been reported, namely, in sample stirring, temperature control, limited fibre

life, fibre breakage and elevated cost of fibres [35].

In some studies sample extraction has been performed at room temperature $\left(20 \pm 1{ }^{\circ} \mathrm{C}\right)[45]$ or $\left(20 \pm 3{ }^{\circ} \mathrm{C}\right)$ [18]. Sá et al. assessed the temperature effect in the range 30 to $65^{\circ} \mathrm{C}$, and concluded that $55^{\circ} \mathrm{C}$ was the optimum extraction temperature [8].

In HS-SPME analysis, the use of an internal standard (IS) may overcome some of the difficulties in this technique. Silva et al. [18] reported the use of 2-bromo-1-chloropropane as $\mathrm{IS}$, while fluorobenzene
The analysis of THMs in the air of indoor pools is still understudied. However there are some references to the use of different injection/ extraction methods by several authors. Aggazzotti et al. [14] and Fantuzzi et al. [40] collected the air with screw-capped glass vials and Tedlar bags, respectively. Then, gas tight syringes were used to inject the samples directlyinto the GC-ECD apparatus.

Solid sorbents are being used extensively to sample contaminants in air. A small tube containing a solid sorbent is convenient to use and transport, to concentrate trace contaminants and can be used by a worker to determine breathing zone concentrations [33]. This procedure is relatively simple but it is an expensive technique due the fact that tubes cannot be reused.

This technique utilizes a small pump to draw the air sample through a bed of solid sorbent. The solid sorbent is usually charcoal, silica gel or alternative sorbents such as the Chromosorb, Poropak, Tenax and other porous polymers [33]. NIOSH 1003 and INRS 029 are standard methods that can be applied for the determination of THMs in air samples with solid sorbent tubesand GC-FID analysis.

Table 5

Real values, codified levels and results (sum of the peak areas of all THMs studied) for the first $2^{3}$ experimental design.

\begin{tabular}{lllll}
\hline Experiment & $\begin{array}{l}\text { Extraction } \\
\text { temperature }\left({ }^{\circ} \mathrm{C}\right)\end{array}$ & $\begin{array}{l}\text { Extraction time } \\
(\mathrm{min})\end{array}$ & $\begin{array}{l}\text { Desorption time } \\
(\mathrm{min})\end{array}$ & $\begin{array}{l}\sum \text { Areas } \\
\left(\times 10^{-7}\right)\end{array}$ \\
\hline & & & & \\
& & & & \\
1 & $40(-1)$ & $15(-1)$ & $4(-1)$ & 4.95 \\
2 & $70(+1)$ & $30(+1)$ & $4(-1)$ & 4.31 \\
3 & $40(-1)$ & $30(+1)$ & $4(-1)$ & 6.28 \\
4 & $70(+1)$ & $15(-1)$ & $8(+1)$ & 5.16 \\
5 & $40(-1)$ & $15(-1)$ & $8(+1)$ & 3.34 \\
6 & $70(+1)$ & $30(+1)$ & $8(+1)$ & 6.03 \\
7 & $40(-1)$ & $30(+1)$ & $8(+1)$ & 5.15 \\
8 & $70(+1)$ & $22.5(0)$ & $6(0)$ & 5.39 \\
9 & $55(0)$ & & & 5.29 \\
10 & & & & 5.57 \\
11 & & & & \\
\hline
\end{tabular}



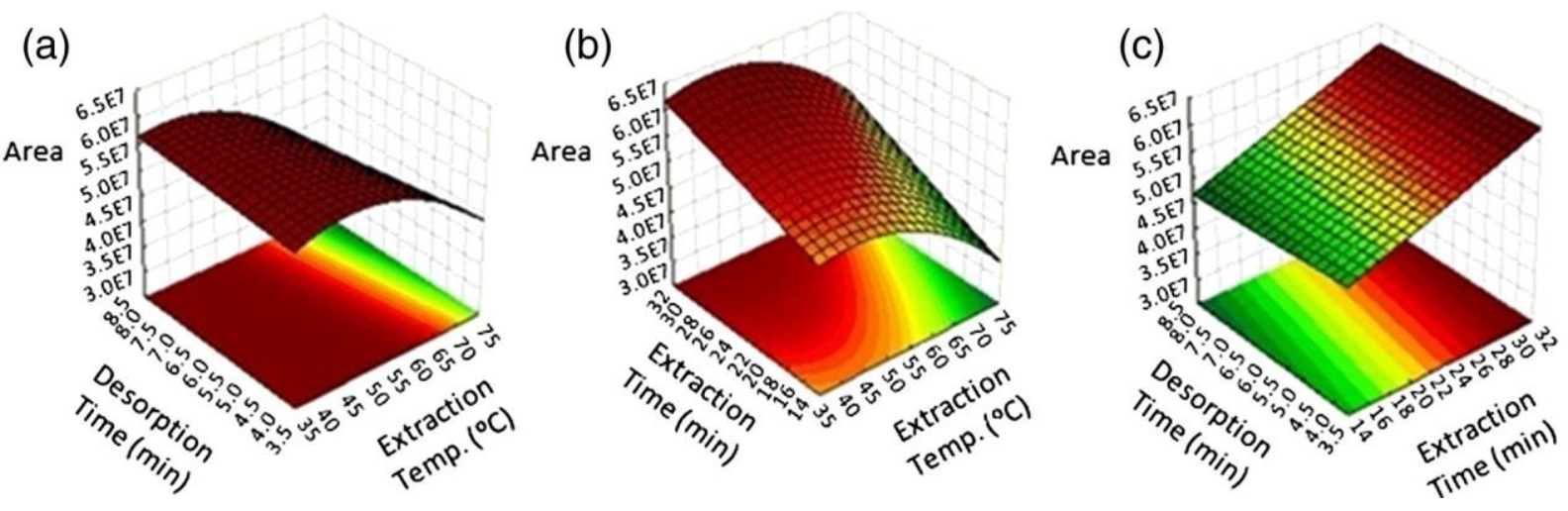

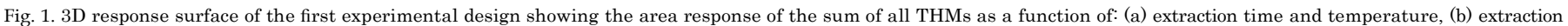
temperature and desorption time and (c) extraction and desorption time.

Silva et al. [18] relied on NIOSH 1003 using activated carbon tubes. Desorption was performed using $1 \mathrm{~mL}$ of $\mathrm{CS}_{2}$ and allowing it to stand for $30 \mathrm{~min}$ with occasional agitation. A volume of $1 \mu \mathrm{L}$ was injected into a GC-FID equipment.

Erdinger et al. [12] described the determination of THMs concentration in air samples by collecting $10 \mathrm{~L}$ of air on activated carbon adsorbents. THMs were desorbed in a headspace vial using $3^{-}$ phenoxybenzylalcohol at $110^{\circ} \mathrm{C}$ for $30 \mathrm{~min}$ and analysis was performed by GC-ECD.

In the P\&T technique, samples are collected by pulling air through a tube containing a thermally stable sorbent bed [33]. The tube is heated and the desorbed compounds are purged directly into a gas chromatograph. This technique eliminates the use of solvents and other handling operations, is more sensitive and the collection tubes are reusable [33].

Caro and Gallego [46] have developed a sensitive and reliable method for the determination of THMs in air samples through sorbent tubes and thermal desorption followed by GC-MS analysis. They tested three commercial sorbent materials and concluded that Chromosorb 102 is the most appropriate sorbent for air sampling because of its high adsorption efficiency. Thermal desorption was carried out for 10 $\min$ at $200^{\circ} \mathrm{C}$ allowing the method to reach a LOD of $0.01 \mathrm{\mu g} \mathrm{m}^{-3}$.

Bessonneau et al. [10] used a stainless thermal desorption tube containing $300 \mathrm{mg}$ of Tenax and obtained a LOD between 0.2 and $0.5 \mu \mathrm{g} \mathrm{m}^{-3}$, when using a GC-MS equipment.

Sá et al. [8] described a new approach based on HS-SPME and GCECD analyses. A $75 \mu \mathrm{m}$ CAR/PDMS fibre was used to extract for $50 \mathrm{~min}$ $40 \mathrm{~mL}$ of air at $30^{\circ} \mathrm{C}$. With this configuration it was possible to achieve LODs ranging between 1.25 and $2.5 \mu \mathrm{g} \mathrm{m}^{-3}$ and RSDs between 5 and $10 \%$.

Considering the importance of assessing the presence of THMs in swimming pool water samples and the extraction methods that can be used, HS-SPME has been selected based on its main advantages,

\section{Table 6}

Real values, codified levels, and results (sum of the peak areas of all THMs studied) for the second $2^{3}$ experimental design.

\begin{tabular}{lllll}
\hline Experiment & $\begin{array}{l}\text { Extraction temperature } \\
\left({ }^{\circ} \mathrm{C}\right)\end{array}$ & $\begin{array}{l}\text { Extraction time } \\
(\mathrm{min})\end{array}$ & $\begin{array}{l}\text { Desorption time } \\
(\mathrm{min})\end{array}$ & $\begin{array}{l}\text { iAreas } \\
\left(\times 10^{-7}\right)\end{array}$ \\
\hline 1 & $35(-1)$ & $20(-1)$ & $4(-1)$ & 6.96 \\
2 & $55(+1)$ & $20(-1)$ & $4(-1)$ & 7.34 \\
3 & $35(-1)$ & $30(+1)$ & $4(-1)$ & 7.52 \\
4 & $55(+1)$ & $30(+1)$ & $4(-1)$ & 6.27 \\
5 & $35(-1)$ & $20(-1)$ & $6(+1)$ & 7.18 \\
6 & $55(+1)$ & $20(-1)$ & $6(+1)$ & 6.46 \\
7 & $35(-1)$ & $30(+1)$ & $6(+1)$ & 7.45 \\
8 & $55(+1)$ & $30(+1)$ & $6(+1)$ & 5.31 \\
9 & $45(0)$ & $25(0)$ & $5(0)$ & 9.38 \\
10 & & & & 8.18 \\
11 & & & & 8.34 \\
\hline
\end{tabular}

namely, minimal sample pre-treatment, simplicity, and fibre reusability. The purpose of this study was to optimize the HS-SPME extraction conditions of TCM, BDCM, CDBM and TBM from water samples using a $2^{3}$ factorial design. The developed method was then applied to a set of 27 swimming water samples from Portugal.

\section{Material and methods}

\subsection{Standards and reagents}

A standard mixture of THMs (TCM, BDCM, CDBM and TBM) with a concentration of $2000 \mu \mathrm{g} \mathrm{mL} \mathrm{m}^{-1}$ in methanol (Supelco) was used. A 100 $\mu \mathrm{m}$ polydimethylsiloxane (PDMS) fibre supplied by Supelco was chosen for application of the HS-SPME technique.

An intermediate standard stock solution of THMs $20,000 \mu \mathrm{g} \mathrm{L}^{-1}$ was obtained by diluting the THMs standard mixture with methanol (gradient grade Merck) and was stored at $-18^{\circ} \mathrm{C}$. Calibration standards were prepared at 5.0, 25.0, 50.0, 100.0 and $150.0 \mu \mathrm{g} \mathrm{L}^{-1}$, by diluting the intermediate standard solution with ultrapure water $(18.2 \mathrm{M} \Omega \mathrm{cm})$ obtained from a Simplicity 185 system (Millipore). Sodium chloride (99.9\%) from Merck was used in the extraction step and sodium thiosulphate pentahydrate (Merck) was used to prevent the formation of THMs after swimming pool water sample collection.

Glass material was washed with tap water and detergentfollowed, successively, by deionized water, acetone (VWR) and deionized water. Finally, the material was washed with ultrapure water and placed in a drying oven at approximately $100{ }^{\circ} \mathrm{C}$ for $2 \mathrm{~h}$ to remove any traces of compounds that may contaminate subsequent samples.

\subsection{Water sampling}

Water samples were collected in $40 \mathrm{~mL}$ screw-capped amber glass vials containing $5 \mathrm{mg}$ of sodium thiosulphate pentahydrate $(0.0125 \%$ w/v). Water was sampled near the deck level, away from the water inlets, $20 \mathrm{~cm}$ away from the sides and at a $20 \mathrm{~cm}$ depth. After collection, the samples were stored in a refrigerator at $4{ }^{\circ} \mathrm{C}$ until further analysis. Samples were collected in 2012, between April and October, in the Northwest region ofPortugal.

\subsection{Gas chromatographic system and conditions}

Separation and identification of THMs were carried out on a Shimadzu gas chromatograph GC-2010, equipped with an electron capture detector (ECD) and a capillary column (TG-5MS $30 \mathrm{~m} \times$ $0.25 \mathrm{~mm} \times 0.25 \mu \mathrm{m}$ (Thermo Scientific) or a ZB-XLB $30 \mathrm{~m} \times$ $0.25 \mathrm{~mm} \times 0.25 \mu \mathrm{m}$ (Zebron, Phenomenex)). Helium was used as carrier gas with a flow rate of $1.2 \mathrm{~mL} \mathrm{~min}^{-1}$ and nitrogen was used as makeup gas with a flow rate of $30 \mathrm{~mL} \mathrm{~min}{ }^{-1}$. The oven was held at $40{ }^{\circ} \mathrm{C}$ for $2 \mathrm{~min}$, then was ramped at $10^{\circ} \mathrm{C} \mathrm{min}^{-1}$ to $100{ }^{\circ} \mathrm{C}$, held 


\section{(a)}

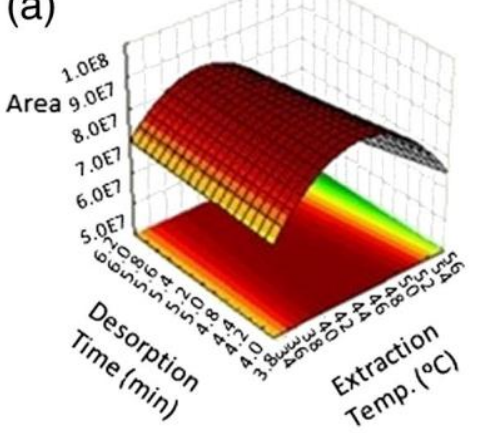

(b)

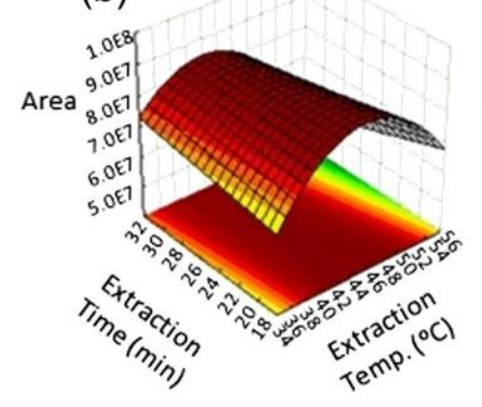

(c)

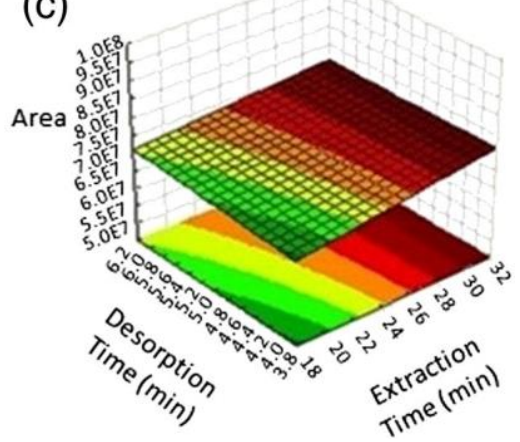

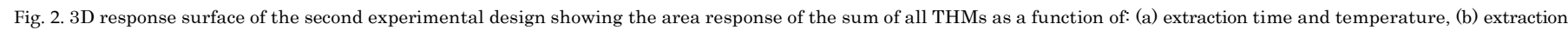
temperature and desorption time and (c) extraction and desorption time.

for $2 \mathrm{~min}$ and ramped again to the final temperature of $150{ }^{\circ} \mathrm{C}$ at $15^{\circ} \mathrm{C} \mathrm{min}{ }^{-1}$ where it was held for $3 \mathrm{~min}$. The injector and detector temperatures were $250^{\circ} \mathrm{C}$ and $300^{\circ} \mathrm{C}$, respectively.

\subsection{HS-SPME extraction procedure}

A volume of $1.6 \mathrm{~mL}$ of a standard aqueous solution containing all four THMs or of a swimming pool water sample was transferred to a

$4 \mathrm{~mL}$ screw-capped vial (sealed with a Teflon-lined silicon septum) containing $25 \% \mathrm{w} / \mathrm{v}$ of sodium chloride and a magnetic bar. Then, the fibre was inserted in the vial through the septum and the set was placed in a water bath heated by a heating plate with a stirrer (SCW-160, SBS). The agitation speed was fixed at $300 \mathrm{rpm}$ and the temperature was kept constant at the established value for each assay. The analytes' extraction was performed in the headspace during the established time. Immediately after extraction, the fibre was inserted directly into the gas chromatograph injector where the analytes are thermally desorbed.

All standard solutions and swimming pool water samples were analysed in duplicate. All statistical analyses were made using the software Statistica version 8.0 (StatSoft, Inc., Tulsa, UK).

\section{Results and discussion}

\subsection{HS-SPME optimization using $2^{3}$ factorial design}

The factorial experimental design allows a large number of factors to be screened simultaneously to determine which ones have significant effects on theresponse.

Extraction temperature and time, and the desorption time were the control factors for the HS-SPME optimization. For these 3 factors, two composite $2^{3}$ factorial designs with a replica were used. Therefore, tests were conducted with 8 experiments, one replica for each test and 3 replicas at the centre. It was considered that the response variable to be optimized was the sum of the chromatogram peak areas of all the compounds analysed and that its highest value gave the most favourable response. The levels chosen for each process variable were based on published studies Thus, for the first design, extraction temperature varied from 40 to $70{ }^{\circ} \mathrm{C}$, extraction time from 15 to
$30 \mathrm{~min}$ and desorption time from 4 to $8 \mathrm{~min}$. The optimization tests were performed using a solution containing $25 \mu \mathrm{g} \mathrm{L} \mathrm{L}^{-1}$ for each of the analytes and keeping the chromatographic conditions constant.

Table 5 shows the description of the experiments and the relation between codified and real experimental values selected for the first experimental design. Low and high levels are denoted by $(-1)$ and $(+1)$, respectively, and the central points as (0).

The statistical evaluation of the main effects and interactions of the HS-SPME optimization was performed by the analysis of variance (ANOVA).

The response surface $3 \mathrm{D}$ plots for the first factorial design are represented in Fig. 1. The Statistica 8.0 software was used to build the response surfaces, with the variable parameters represented in the abscissa and the response area shown in the ordinate.

The F-test indicated a value of 10.04 with a $99 \%$ confidence level and the variance obtained was $2.40 \times 10^{13}$.

The response surface representations from the first experimental design point out that on the second planning it must be taken into account a decrease in the extraction temperature and an increase in the extraction time. According to Pellati et al. [47], the increase in extraction temperature increases the headspace concentration of the volatile compounds, favouring the extraction. However, SPME involves an exothermic process and the extraction of compounds decreases as the temperature increases. Thus, for the second experimental design the temperature's extreme levels were set at 35 and $55^{\circ} \mathrm{C}$ and extraction time was varied from 20 to $30 \mathrm{~min}$.

The statistical analysis shows that desorption time is not a significant factor. Therefore, on the second experimental design the value of the highest level was slightly reduced (from 8 to $6 \mathrm{~min}$ ) (Table 6).

The response surface $3 \mathrm{D}$ plots for the second factorial design are representedin Fig. 2.

Although Fig. 2(c) points out to an increase in extraction time, the mean of the responses is maximum for the central values. Thereby it was assumed that the optimal conditions were found for anextraction temperature of $45{ }^{\circ} \mathrm{C}$, an extraction time of $25 \mathrm{~min}$ and a desorption time of $5 \mathrm{~min}$.

The variance obtained for the second experimental design was 2.56 $\times 10^{13}$.

Table 7

Performance of the proposed HS-SPME method showing a typical calibration equation obtained using the TG-5MS $30 \mathrm{~m} \times 0.25 \mathrm{~mm} \times 0.25 \mu \mathrm{m}$ column .

\begin{tabular}{|c|c|c|c|c|c|c|}
\hline \multirow[b]{2}{*}{ Compound } & \multirow[b]{2}{*}{$\begin{array}{l}\mathrm{t}_{\text {ret }} \\
(\min )\end{array}$} & \multirow[b]{2}{*}{ Calibration equation } & \multirow[b]{2}{*}{$\mathrm{R}^{2}$} & \\
\hline & & & & $\begin{array}{l}\text { LOD } \\
\left(\mu \mathrm{g} \mathrm{L}^{-1}\right)\end{array}$ & $\begin{array}{l}\mathrm{LOQ} \\
\left(\mu \mathrm{g} \mathrm{L}^{-1}\right)\end{array}$ & $\begin{array}{l}\operatorname{RSD}(\%) \\
\left(5 \mu \mathrm{gL}^{-1}, \mathrm{n}=2\right)\end{array}$ \\
\hline TCM & 3.29 & $y=36137 x+179884$ & 0.999 & 4.0 & 13.3 & 4.8 \\
\hline BDCM & 4.13 & $y=296500 x+885230$ & 0.997 & 10.1 & 33.6 & 5.3 \\
\hline CDBM & 5.66 & $y=328183 x+1301534$ & 0.990 & 11.8 & 39.2 & 9.8 \\
\hline TBM & 7.39 & $y=171676 x+1385850$ & 0.987 & 10.7 & 35.7 & 10.0 \\
\hline
\end{tabular}




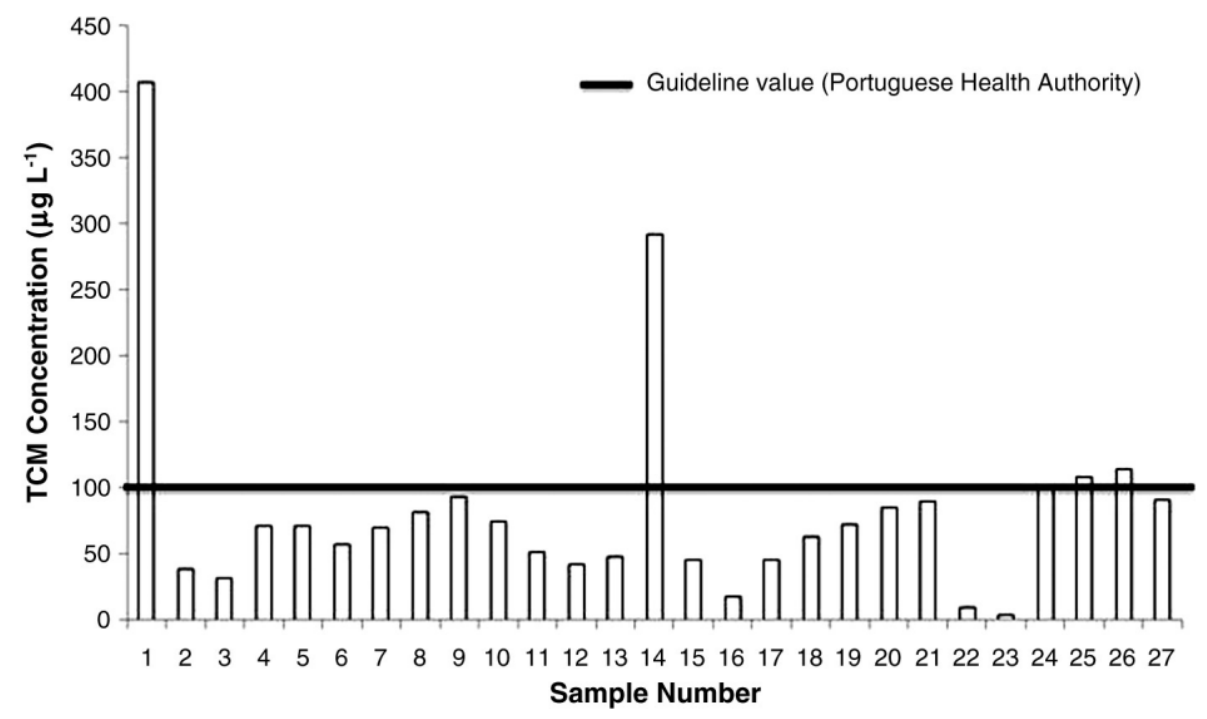

Fig. 3. Mean TCM values in indoor swimming pool water samples using the optimized HS-SPME method.

\subsection{Analytical performance and validation}

Using the optimal HS-SPME conditions obtained, calibration curves were constructed based on five concentration levels in the range 5 $150 \mu \mathrm{g} \mathrm{L}{ }^{-1}$. Two different GC columns were used in this work (a TG5 MS $30 \mathrm{~m} \times 0.25 \mathrm{~mm} \times 0.25 \mu \mathrm{m}$ and a ZB-XLB $30 \mathrm{~m} \times 0.25 \mathrm{~mm} \times$ $0.25 \mu \mathrm{m})$. Both columns showed a similar analytical performance although the retention times under the experimental conditions (Section 2.3) were slightly higher for the ZB-XLB column, except for TCM (retention times in the range 3.09-8.39 min). Good linearity was observed for both columns and the $\mathrm{R}^{2}$ values were always higher than 0.98 .

The analytical figures of merit of the proposed HS-SPME method are shown in Table 7. For the TG-5MS column, the limits of detection (LODs) estimated from the calibration data were in the range $4.0-11.8 \mu \mathrm{g} \mathrm{L}^{-1}$ and the corresponding limits of quantification (LOQs) were between 13.3 and $39.2 \mu \mathrm{g} \mathrm{L}^{-1}$. Regarding the precision of the method, intra-day coefficient of variation (RSD \%), for a $5 \mu \mathrm{gL}^{-1}$ standard solution, ranged between 4.8 and $10.0 \%$.

\subsection{THMs in swimming pool water samples}

A set of 27 indoor swimming pool water samples was analysed using the optimized HS-SPME method (Fig. 3). TCM was the only THM found in all the analysed samples. TCM concentrations were below the LOQ for two of the samples, with estimated values of 4.5 and $9.9 \mu \mathrm{g} \mathrm{L}^{-1}$. The other swimming pool water samples presented TCM levels ranging from 17.4 to $406.5 \mu \mathrm{gL}^{-1}$. Three of these samples were analysed by an external laboratory, using an accredited independent method. The

results obtained for TCM by the proposed method are comparable to

Table 8

Summary of the results for some physical and chemical parameters for the swimming pool water samples analysed.

\begin{tabular}{|c|c|c|c|c|}
\hline Parameter & $\mathrm{N}$ & Minimum & Maximum & Mean \\
\hline Water temperature $\left({ }^{\circ} \mathrm{C}\right)$ & 4 & 27.5 & 28.1 & 27.8 \\
\hline $\mathrm{pH}$ & 24 & 7.13 & 8.0 & 7.47 \\
\hline Free chlorine $\left(\mathrm{mg} \mathrm{L}^{-1}\right)$ & 24 & 0.06 & 5.5 & 1.51 \\
\hline Combined chlorine $\left(\mathrm{mg} \mathrm{L}^{-1}\right)$ & 20 & 0.1 & 1.1 & 0.46 \\
\hline Total chlorine $\left(\mathrm{mg} \mathrm{L}^{-1}\right)$ & 20 & 0.8 & 6.1 & 2.26 \\
\hline Chloride $\left(\mathrm{mg} \mathrm{L}^{-1}\right)$ & 20 & 29 & 312 & 89.7 \\
\hline Conductivity $\left(\mu \mathrm{S} \mathrm{cm}^{-1}\right)$ & 20 & 257.0 & 1181 & 561.6 \\
\hline Total organic carbon (TOC) $\left(\mathrm{mg} \mathrm{L}^{-1}\right)$ & 4 & 7.12 & 7.23 & 7.18 \\
\hline Oxidability by $\mathrm{KMnO}_{4}\left(\mathrm{mgO}_{2} \underline{\mathrm{L}}^{-1}\right)$ & 20 & 1.0 & 3.9 & 2.1 \\
\hline
\end{tabular}

the ones obtained by the external laboratory (in parenthesis): $43.3 \mu \mathrm{g} \mathrm{L}^{-1}\left(47.0 \mu \mathrm{g} \mathrm{L}^{-1},-7.9 \%\right) ; 99.6 \mu \mathrm{g} \mathrm{L}^{-1}(123.0,-19 \%)$ and $368.7 \mu \mathrm{g} \mathrm{L}^{-1}\left(323 \mu \mathrm{g} \mathrm{L}^{-1}, 14.1 \%\right)$.

Four of the samples exceeded the guideline parametric value for total THMs $\left(100 \mu \mathrm{gL}^{-1}\right)$ established by the Portuguese Health Authority for swimming pool water [23], and two of these values were higher than $150 \mu \mathrm{g} \mathrm{L}^{-1}\left(292.1\right.$ and $\left.406.5 \mu \mathrm{g} \mathrm{L}^{-1}\right)$. The average TCM concentration was $90.4 \mu \mathrm{g} \mathrm{L} \mathrm{L}^{-1}$, if all the quantified samples were considered and $67.9 \mu \mathrm{gL}^{-1}$ if the two highest TCM values are excluded.

The TCM values obtained are within the values found in the literature (Table 1).

Several physical and chemical parameters related to swimming pool water quality were measured at the time of sample collection, in the indoor swimming pools (Table 8). The water temperature ranged from 27 to $28^{\circ} \mathrm{C}$, while the $\mathrm{pH}$ value was in the range of 7.1 to 8.0. Data on free and combined chlorine ranged from 0.06 to $5.5 \mathrm{mg} \mathrm{L}^{-1}$ and from 0.1 to $1.1 \mathrm{mg} \mathrm{L}^{-1}$, respectively. Chloride concentrations up to 312 $\mathrm{mg} \mathrm{L}^{-1}$ were found, with a mean value of $89.7 \mathrm{mg} \mathrm{L}^{-1}$.

\section{Conclusions}

This paper presents an overview of the different techniques used to determine THMs in swimming pool water and air samples, referring to the main advantages and disadvantages of each method and pointing out the conditions reported in the literature.

HS-SPME was applied to the determination of THMs in swimming pool water. Experimental parameters such as extraction temperature, and extraction and desorption times were optimized by conducting

two 2 experimental designs. The optimal conditions were obtained

for an extraction temperature of $45^{\circ} \mathrm{C}$, an extraction time of $25 \mathrm{~min}$ and a desorption time of $5 \mathrm{~min}$.

The method was successfully applied to a set of 27 swimming pool water samples collected in the Northwest region of Portugal. TCM was the only THM detected with levels between 4.5 and

$406.5 \mu \mathrm{g} \mathrm{L}^{-1}$. Four of the samples exceeded the guideline value for total THMs $\left(100 \mu \mathrm{g} \mathrm{L}^{-1}\right)$ established by the Portuguese Health Authority for swimming pool water.

Acknowledgements

This work was supported by CIETI (grant BIC CIETI_NITAE/2012) and Fundação para a Ciência e Tecnologia (PEst-C/EQB/LA0006/2011). The authors wish to thank the Centro de Estudos de Águas of the Instituto 
Superior de Engenharia do Porto for all the collaboration in this study, particularly to Rosária Santos and Marta Pinto.

\section{References}

[1] WHO, Guidelines for safe recreational water environments, Volume 2 - swimming pools and similar environments, World Health Organization, Geneva, 2006. 60-79.

[2] IARC Monographs on the Evaluation of the Carcinogenic Risks to Humans, Some Chemicals that Cause Tumours of the Kidney or Urinary Bladder in Rodents and Some Other Substances, in: IARC (Ed.), 73, Lyon, France, 1999, pp. 131-182.

[3] IARC Monographs on the Evaluation of the Carcinogenic Risks to Humans, Chlorinated drinking-water, chlorination by-products, in: IARC (Ed.), Some Other Halogenated Compounds; Cobalt and Cobalt Compounds, 52, Lyon, France, 1991 pp. $179-212$.

[4] IARC Monographs on the Evaluation of the Carcinogenic Risks to Humans, in: IARC (Ed.), Re-evaluation of Some Organic Chemicals, Hydrazine and Hydrogen Peroxide, 71, Lyon, France, 1999, pp. 1295-1304.

[5] United States Department of Health and Human Services, Public Health Service, Agency for Toxic Substances and Disease Registry, Toxicological Profile for Chloroform, Agency for Toxic Substances and Disease Registry, Atlanta, 1997. 179.

[6] United States Public Health Service, Agency for Toxic Substances and Disease Registry and U.S. EPA, Toxicological Profile for Bromodichloromethane, Agency for Toxic Substances and Disease Registry, Atlanta, 1989. 37.

[7] United States Department of Health and Human Services, Public Health Service, Agency for Toxic Substances and Disease Registry, Toxicological Profile for Bromoform and Dibromochloromethane, Agency for Toxic Substances and Disease Registry, Atlanta, 2005. 119.

[8] C.S.A. Sá, R.A.R. Boaventura, I.B. Pereira, Analysis of trihalomethanes in water and air from indoor swimming pools using HS-SPME/GC/ECD, J. Environ. Sci. Health Part A 46 (2011) $355-363$.

[9] M.J. Chen, C.H. Lin, J.M. Duh, W.S. Chou, H.T. Hsu, Development of a multi-pathway probabilistic health risk assessment model for swimmers exposed to chloroform in indoor swimming pools, J. Hazard. Mater. 185 (2011) 1037-1044.

[10] V. Bessonneau, M. Derbez, M. Clément, O. Thomas, Determinants of chlorination by-products in indoor swimming pools, Int. J. Hyg. Environ. Health 215 (2011) 76-85.

[11] U. Lahl, K. Bätjer, J.v. Düszeln, B. Gabel, B. Stachel, W. Thiemann, Distribution and balance of volatile halogenated hydrocarbons in the water and air of covered swimming pools using chlorine for water disinfection, Water Res. 15 (1981) 803-814

[12] L. Erdinger, K.P. Kühn, F. Kirsch, R. Feldhues, T. Fröbel, B. Nohynek, T. Gabrio, Pathways of trihalomethane uptake in swimming pools, Int. J. Hyg. Environ. Health 207 (2004) 571-575.

[13] G. Aggazzotti, G. Fantuzzi, E. Righi, P. Tartoni, T. Cassinadri, G. Predieri, Chloroform in alveolar air of individuals attending indoor swimming pools, Arch. Environ. Health 48 (1993) $250-254$.

[14] G. Aggazzotti, G. Fantuzzi, E. Righi, G. Predieri, Environmental and biological monitoring of chloroform in indoor swimming pools, J. Chromatogr. A 710 (1995) 181-190.

[15] G. Aggazzotti, G. Fantuzzi, E. Righi, G. Predieri, Blood and breath analyses as biological indicators of exposure to trihalomethanes in indoor swimming pools, Sci. Total Environ. 217 (1998) 155-163.

[16] G. Fantuzzi, E. Righi, G. Predieri, G. Ceppelli, F. Gobba, G. Aggazzotti, Occupational exposure to trihalomethanes in indoor swimming pools, Sci. Total Environ. 264 (2001) 257-265.

[17] M.C. Aprea, B. Banchi, L. Lunghini, M. Pagliantini, A. Peruzzi, G. Sciarra, Disinfection of swimming pools with chlorine and derivatives: formation of organochlorinated and organobrominated compounds and exposure of pool personnel and swimmers, Nat. Sci. 2 (2010) 68-78.

[18] Z.I. Silva, M.H. Rebelo, M.M. Silva, A.M. Alves, M.C. Cabral, A.C. Almeida, F.R. Aguiar, A.L. Oliveira, A.C. Nogueira, H.R. Pinhal, P.M. Aguiar, A.S. Cardoso, Trihalomethane in Lisbon indoor swimming pools: occurrence, determining factors, and health risk classification, J. Toxicol. Environ. Health A 75 (2012) 878-892.

[19] L.S. Marina, J. Ibarluzea, M. Basterrechea, F. Goñi, E. Ulibarrena, J. Artieda, I. Orruño, Contaminación del aire interior y del agua de baño en piscinas cubiertas de Guipúzcoa, Gac. Sanit. 23 (2009) 115-120.

[20] S.D. Richardson, D.M. DeMarini, M. Kogevinas, P. Fernandez, E. Marco, C. Lourencetti, C. Ballesté, D. Heederik, K. Meliefste, A.B. McKague, R. Marcos, L. Font-Ribera, J.O. Grimalt, C.M. Villanueva, What's in the pool? A comprehensive identification of disinfection by-products and assessment of mutagenicity of chlorinated andbrominated swimming pool water, Environ. Health Perspect. 118 (2010) 1523-1530.
[21] C. Lourencetti, J.O. Grimalt, E. Marco, P. Fernandez, L. Font-Ribera, C.M. Villanueva, M. Kogevinas, Trihalomethanes in chlorine and bromine disinfected swimming pools: air-water distributions and human exposure, Environ. Int. 45 (2012) 59-67.

[22] Council Directive 98/83/EC of 3 November 1998 on the quality of water intended for human consumption, Off. J. Eur. Commun. L 330 (1998) 32-54.

[23] Portuguese Ministry of Health, Direcção-Geral da Saúde, Circular Normativa $\mathrm{N}^{\circ}$ 14/DA2009. 13-14.

[24] E.P.A. US, Stage 2 disinfectants and disinfection byproducts rule (Stage 2 DBPR) 71 FR 388, 71 (2006) 388-493.

[25] WHO, Guidelines for Drinking-water Quality, fourth edition World Health Organization, Geneva, 2011. 427.

[26] Federal-Provincial-Territorial-Committee on Drinking Water, Guidelines for Canadian Drinking Water Quality: Guideline Technical Document, Trihalomethanes, Health Canada, Ontario, 2006, p. 1, (with April 2009 addendum).

[27] Commission Directive 2000/39/EC of 8 June 2000 establishing a first list of indicative occupational exposure limit values in implementation of Council Directive 98/24/EC on the protection of the health and safety of workers from the risks related to chemical agents at work, Off. J. Eur. Commun. L 142 (2000) 47-50.

[28] Occupational Safety and Health Administration, Occupational Safety and Health Standards, Toxic and Hazardous Substances, Standard 1910.1000 - Air Contaminants (Table Z-1).

[29] National Institute for Occupational Safety, Pocket Guide to Chemical Hazards, (Publication No. 2005-149) U.S. Department of Health and Human Services, Centers for Disease Control and Prevention, 2007. 34 and 65.

[30] ACGIH, www.acgih.org/8th January of 2013(accessed on).

[31] J. Parinet, S. Tabaries, B. Coulomb, L. Vassalo, J.L. Boudenne, Exposure levels to brominated compounds in seawater swimming pools treated with chlorine, Water Res. 46 (2012) 828-836.

[32] D.H. Cho, S.H. Kong, S.G. Oh, Analysis of trihalomethanes in drinking water using headspace-SPME technique with gas chromatography, Water Res. 37 (2003) 402408.

[33] R.G. Melcher, T.L. Peters, H.W. Emmel, Sampling and sample preparation of environmental material, Top. Curr. Chem. 134 (1986) 59-123.

[34] J.L.P. Pavón, S.H. Martín, C.G. Pinto, B.M. Cordero, Determination of trihalomethanes in water samples: a review, Anal. Chim. Acta. 629 (2008) 6-23.

[35] S. Shegefti, H. Sereshti, S. Samadi, Measurement of chloroform in swimming pools' waters and swimmers' blood, Iran. J. Publ. Health 38 (2009) 103-110.

[36] M. Biziuk, J. Namiesnik, J. Czerwifiski, D. Gorlo, B. Makuch, W. Janicki, Z. Polkowska, L. Wolska, Occurrence and determination of organic pollutants in tap and surface waters of the Gdańsk district, J. Chromatogr. A 733 (1996) 171-183.

[37] B. Buszewski, T. Ligor, Application of different extraction methods for the quality control of water, Water Air Soil Pollut. 129 (2001) 155-165.

[38] H. Chu, M.J. Nieuwenhuijsen, Distribution and determinants of trihalomethane concentrations in indoor swimming pools, Occup. Environ. Med. 59 (2002) 243247.

[39] M. Panyakapo, S. Soontornchai, P. Paopuree, Cancer risk assessment from exposure to trihalomethanes in tap water and swimming pool water, J. Environ. Sci. 20 (2008) 372-378.

[40] G. Fantuzzi, E. Righi, G. Predieri, P. Giacobazzi, K. Mastroianni, G. Aggazzotti, Prevalence of ocular, respiratory and cutaneous symptoms in indoor swimming pool workers and exposure to disinfection by-products (DBPs), Int. J. Environ. Res. Public Health 7 (2010) 1379-1391.

[41] J. Caro, A. Serrano, M. Gallego, Direct screening and confirmation of priority volatile organic pollutants in drinking water, J. Chromatogr. A 1138 (2007) 244-250.

[42] A. Serrano, M. Gallego, Rapid determination of total trihalomethanes index in drinking water, J. Chromatogr. A 1154 (2007) 26-33.

[43] J. Lee, K. Ha, K. Zoh, Characteristics of trihalomethane (THM) production and associated health risk assessment in swimming pool waters treated with different disinfection methods, Sci. Total Environ. 407 (2009) 1990-1997.

[44] S.K. Golfinopoulos, T.D. Lekkas, A.D. Nikolaou, Comparison of methods for determination of volatile organic compounds in drinking water, Chemosphere 45 (2001) 275-284.

[45] M.A. Stack, G. Fitzgerald, S. O'Connell, K.J. James, Measurement of trihalomethanes in potable and recreational waters using solid phase micro extraction with gas chromatography-mass spectrometry, Chemosphere 41 (2000) 1821-1826.

[46] J. Caro, M. Gallego, Development of a sensitive thermal desorption method for the determination of trihalomethanes in humid ambient and alveolar air, Talanta 76 (2008) 847-853.

[47] F. Pellati, S. Benvenuti, F. Yoshizaki, D. Bertelli, M.C. Rossi, Headspace solid-phase microextraction-gas chromatography-mass spectrometry analysis of the volatile compounds of Evodia species fruits, J. Chromatogr. A 1087 (2005) 265-273. 